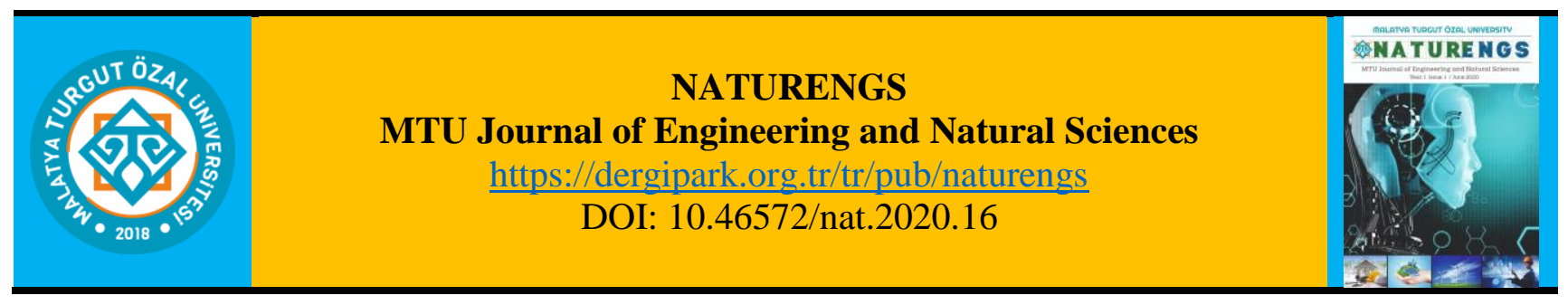

\title{
Investigation of Obesity Tendency of University Students with Bioelectric Impedance Body Analyzer
}

\author{
Aziz AKSOY ${ }^{*}$, Halime SELEN ${ }^{2}$, Seda OĞUR ${ }^{3}$ \\ ${ }^{1}$ Department of Bioengineering, Faculty of Engineering and Natural Sciences, Malatya Turgut Özal University, \\ Malatya, Turkey. \\ ${ }^{2}$ Department of Nutrition and Dietetic, Faculty of Health Science, Ağrı İbrahim Çeçen University, Ağrı, Turkey. \\ ${ }^{3}$ Department of Nutrition and Dietetic, Health Highschool, Bitlis Eren University, Bitlis, Turkey.
}

(Received: 06.12.2020; Accepted: 22.12.2020)

\begin{abstract}
In this study, it was aimed to investigate the obesity tendency of the students of Bitlis Eren University with a Bioelectrical Impedance Body Analyzer. A total of 400 students volunteered comprised of 200 males and 200 females were enrolled in the study. According to Body Mass Index (BMI) values were found that $19.5 \%$ of the female 1 students were Underweight, $68.5 \%$ of them were normal weight, $11.0 \%$ of them were overweight and $1.0 \%$ of them were obese, $4.5 \%$ of the boy students were weak, $71.0 \%$ of them were normal weight, $22.0 \%$ of them were overweight and $2.5 \%$ of them were obese. The result of body fat ratio was indicated that while $48.0 \%$ of the female students were in the obese category, $40.0 \%$ of them were determined in the obesity tendency risk group, $56.0 \%$ of the boy students were in the obesity tendency risk group and $26.0 \%$ of them were obese. According to the waist/hip ratio were revealed that $95.5 \%$ of the girl students were in the obesity tendency group and $4.0 \%$ of them were obese, $85.5 \%$ of the boy students were in the obesity tendency group and $4.0 \%$ of them were obese. A significant difference was found between age and gender, fat ratio, waist/hip ratio, and BMI values ( $\mathrm{p}<0.05$ ). University students participating in the study were evaluated. The overweight (Pre-obese) rate was found to be high in students (Female: $11 \%$; Male: $22 \%$ ).
\end{abstract}

Keywords: Obesity, Obesity tendency, Body mass index, Body fat ratio, Waist/hip ratio.

\section{INTRODUCTION}

Overweight and obesity are defined as abnormal or excessive fat accumulation that may impair health $[1,2]$. Although the causes of obesity, which the World Health Organization (WHO) regards as an important public health problem, are not yet fully known, it is thought to be a complicated health problem caused by environmental and genetic factors [3]. It is known that obesity triggers cardiovascular diseases, causes degenerative effects on muscles, bones, and joints, and causes diseases such as dyslipidemia, hypertension, diabetes, arthritis, osteomalacia, osteoporosis, depression, and cancer [4-10]. The increase in the tendency to consume fast-food due to today's technology and especially the fact that the time spent actively is shortening invites obesity [11]. 


\subsection{Body Mass Index (BMI)}

The most common criterion that is utilized for obesity is Body Mass Index (BMI), which is accepted by the World Health Organization and can be used as a criterion for all individuals without the gender difference [12]. BMI is calculated by dividing body weight in $\mathrm{kg}$ by the square of height in meters $\left(\mathrm{kg} / \mathrm{m}^{2}\right)[13]$.

Table 1. BMI Classification in Adults

\begin{tabular}{|l|c|}
\hline Classification & BMI $\left(\mathbf{k g} / \mathbf{m}^{\mathbf{2}}\right)$ \\
\hline Underweight & $<18.5$ \\
\hline Normal range & $18.5-24.9$ \\
\hline Overweight (Pre-obese) & $25.0-29.9$ \\
\hline 1st degree obese & $30.0-34.9$ \\
\hline 2nd degree obese & $35.0-39.9$ \\
\hline 3rd degree obese & $\geq 40$ \\
\hline
\end{tabular}

\subsection{Waist/Hip Ratio}

The waist/hip ratio is expected to be below 0.80 for females and below 0.95 for males [14]. According to WHO should the waist/hip ratio surpass 0.85 in women and 1.0 in men, it is considered as android type obesity [15].

\subsection{Body Fat Ratio}

The body fat ratio is between $18-24 \%$ in adult males and between $25-31 \%$ in adult females. This ratio surpassing $25 \%$ in men and $32 \%$ in women constitutes obesity [16].

\subsection{Body Muscle Weight and Total Body Water}

The muscle weight of the body is not a criterion for defining obesity. Although a high body muscle weight increases BMI, especially in athletes, it cannot be asserted that it demonstrates a tendency to obesity. WHO reports that obesity stems from the accumulation of excess adipose tissue and that this excess fat prompts diseases [16]. On the other hand, excessive body muscle weight provides flexibility, endurance, and dynamism to the body instead of causing diseases. And due to the water retention feature of creatine stores in muscle tissue [17], an increase in total body water is also observed in parallel with the increase in the body muscle.

\subsection{Basal Metabolic Rate (BMR)}

BMR, which is the energy needed for the circulation, respiration, and the continuation of body temperature while the individual is in the full resting state, may vary according to the factors such as body weight, the ratio of muscle and fat in body components, race, age, and genetics [18]. It decreases calorie expenditure via shortening the duration of physical activity of the individual and accordingly causes obesity by decreasing the basal metabolic rate [19]. 


\section{MATERIAL AND METHODS}

To this study; A total of 400 volunteer students, 200 female and 200 male, who studied at Bitlis Eren University between February and May 2015, were included in the study. Participants were informed about the measurement at least one day prior, and the measurement devices were introduced to them. The measurements were made at 09:30 in the morning while the students were hungry. The height measurements of the students were performed via a digital-display Ultrasonic Harpenden Stadiometer (ADE / Hamburg MZ10020) device with a precision degree of $0.1 \mathrm{~cm}$, and no accessories or items that would affect the measurement were allowed [20]. Measurements were performed in the Inbody230 (MW160) Bioelectrical Impedance Body Analyzer [21] through the entrance of height, gender, and age values, and the measurements were made while the students were in a state of complete rest, while they were wearing nothing other than shorts, and at least 12 hours after the students ate the meal. As a result of the conducted measurement, BMI, body fat ratio, waist/hip ratio, body muscle weight, total body water, and basal metabolic rate values were determined.

The data obtained were analyzed through the utilization of IBM SPSS Statistics 20 package program, and Pearson chi-square test was performed to put forth whether the observed values were compatible with expected values, and the Spearman rank correlation coefficient test was utilized to determine the direction of the relationship between variables. Statistical significance level was accepted as $\mathrm{p}<0.05$ for the evaluation of the results.

\section{RESULTS AND DISCUSSION}

The number of female and male students participating in the study has been kept equal; A total of $400(200 \mathrm{~F}+200 \mathrm{M})$ volunteers, consisting of healthy students whose ages, diets are close to each other, participated in the study. The age range of the students is $18-25$, and the mean age is $21.0 \pm 1.65$. In the study in which 400 students participated in total, $2.5 \%$ of the students (10 people) were 18 years old, $16.0 \%$ (64 people) of them were 19 years old, 25.5\% (102 people) of them were 20 years old, $23.0 \%$ (92 people) of them were 21 years old $14.0 \%$ (56 people) of them were 22 years old, $9.75 \%$ ( 39 people) of them were 23 years old, $5.5 \%$ ( 22 people) of them were 24 years old, and $3.75 \%$ (15 people) of them were 25 years old.

Considering the distribution of BMI values of the students who participated in the study, of the female students, $19.5 \%$ (39 people) of them were underweight $68.5 \%$ (137 people) of them were normal, $11 \%$ (22 people) of them were slightly obese, $1 \%$ of them were obese; and of the male students, $4.5 \%$ (9 people) of them were thin, $71 \%$ (142 people) of them were normal, $22 \%$ (44 people) of them were slightly obese, and $2.5 \%$ (5 people) of them were obese. There was a significant difference $(\mathrm{p}<0.05)$ between the gender of the students participating in the study and their value of BMI, and the correlation (r: 0.246) between this difference was weak. Accordingly, it can be asserted that BMI values of female students participating in the study were more normal and lower than those of the male students (Table 2).

Table 2. Percentage distribution of Body Mass Index by gender

\begin{tabular}{|c|c|c|c|c|c|c|}
\hline \multicolumn{3}{|c|}{ Parameters } & \multicolumn{2}{|c|}{ Gender } & \multirow[t]{2}{*}{$\mathbf{p}$} & \multirow[t]{2}{*}{$\mathbf{r}$} \\
\hline & & & $\mathbf{F}$ & $\mathbf{M}$ & & \\
\hline \multirow{6}{*}{$\sum_{\infty}$} & \multirow[t]{2}{*}{$<18.5$} & $\mathrm{n}$ & 39 & 9 & \multirow{6}{*}{$\mathrm{p}<0.05$} & \multirow{6}{*}{ r: 0.246} \\
\hline & & $\%$ & 19.5 & 4.5 & & \\
\hline & \multirow[t]{2}{*}{$18.5-24.9$} & $\mathrm{n}$ & 137 & 142 & & \\
\hline & & $\%$ & 68.5 & 71.0 & & \\
\hline & \multirow[t]{2}{*}{$25.0-29.9$} & $\mathrm{n}$ & 22 & 44 & & \\
\hline & & $\%$ & 11.0 & 22.0 & & \\
\hline
\end{tabular}


There was a significant difference $(\mathrm{p}<0.05)$ between the gender of the students who participated in the study and their body fat ratio (r: 0.891), waist/hip ratio (r: 0.979), total body water (r: 0.823), muscle weight ( $\mathrm{r}$ : 0.826), and BMR ( $\mathrm{r}: 0.819$ ), and the correlation between this difference was immensely strong. According to this, while the body fat ratio and waist/hip ratio of the female students who participated in the study was concentrated above normal values compared to the male students, male students' muscle weight, total body water, and BMR values were concentrated above normal values compared to female students (Table 3).

Table 3. Percentage distribution of body fat ratio, waist/hip ratio, total body water, muscle weight and BMR by gender

\begin{tabular}{|c|c|c|c|c|c|c|c|}
\hline \multicolumn{3}{|l|}{ Parameters } & $\begin{array}{c}\text { Below } \\
\text { Normal } \\
\text { Value }\end{array}$ & $\begin{array}{l}\text { Normal } \\
\text { Value }\end{array}$ & $\begin{array}{c}\text { Above } \\
\text { Normal } \\
\text { Value }\end{array}$ & $\mathbf{p}$ & $\mathbf{r}$ \\
\hline \multirow{4}{*}{ Body Fat Ratio } & $\mathrm{F}$ & $\mathrm{n}$ & 24 & 80 & 98 & \multirow{4}{*}{$\mathrm{p}<0.05$} & \multirow{4}{*}{ r: 0.891} \\
\hline & & $\%$ & 6.0 & 20.0 & 24.5 & & \\
\hline & M & $\mathrm{n}$ & 36 & 112 & 50 & & \\
\hline & & $\%$ & 9.0 & 28.0 & 12.5 & & \\
\hline \multirow{4}{*}{$\begin{array}{l}\text { Waist/Hip } \\
\text { Ratio }\end{array}$} & $\mathrm{F}$ & $\mathrm{n}$ & 1 & 191 & 8 & \multirow{4}{*}{$\mathrm{p}<0.05$} & \multirow{4}{*}{ r: 0.979} \\
\hline & & $\%$ & 0.3 & 47.8 & 2.0 & & \\
\hline & $M$ & $\mathrm{n}$ & 21 & 171 & 8 & & \\
\hline & & $\%$ & 5.3 & 42.8 & 2.0 & & \\
\hline \multirow{4}{*}{$\begin{array}{l}\text { Total Body } \\
\text { Water }\end{array}$} & $\mathrm{F}$ & $\mathrm{n}$ & 39 & 139 & 22 & \multirow{4}{*}{$\mathrm{p}<0.05$} & \multirow{4}{*}{ r: 0.823} \\
\hline & & $\%$ & 19.5 & 69.5 & 11.0 & & \\
\hline & M & $\mathrm{n}$ & 9 & 147 & 44 & & \\
\hline & & $\%$ & 4.5 & 73.5 & 22.0 & & \\
\hline \multirow[t]{4}{*}{ Muscle Weight } & $\mathrm{F}$ & $\mathrm{n}$ & 71 & 126 & 3 & \multirow{4}{*}{$\mathrm{p}<0.05$} & \multirow{4}{*}{ r: 0.826} \\
\hline & & $\%$ & 35.5 & 63.0 & 1.5 & & \\
\hline & M & $\mathrm{n}$ & 23 & 146 & 31 & & \\
\hline & & $\%$ & 11.5 & 73.0 & 15.5 & & \\
\hline \multirow[t]{4}{*}{ BMR } & $\mathrm{F}$ & $\mathrm{n}$ & 65 & 129 & 6 & \multirow{4}{*}{$\mathrm{p}<0.05$} & \multirow{4}{*}{ r: 0.819} \\
\hline & & $\%$ & 32.5 & 64.5 & 3.0 & & \\
\hline & M & $\mathrm{n}$ & 29 & 160 & 11 & & \\
\hline & & $\%$ & 14.5 & 80.0 & 5.5 & & \\
\hline
\end{tabular}

There was a significant difference $(\mathrm{p}<0.05)$ between the age of the students who participated in the study and their BMI (r: 0.204), body fat ratio (r: 0.255), and waist/hip ratio (r: 0.248), and the correlation between this difference was weak. No significant difference $(p>0.05)$ between age and muscle weight, total body water, and BMR was found. When female and male students are grouped by age, it can be said that although BMI, body fat ratio, and waist/hip ratios are greater in the group of older students, they demonstrate similar distributions because the age groups are very close to each other and that they are associated with a weak correlation (Table 4).

According to the data gathered from the study, it can be interpreted by only looking at BMI values that overweight (pre-obese) rate was found to be high in students (Female: 11\%; Male: $22 \%$ ) (Table 2). In a similar study, it was reported that male students have higher BMI values than female students [22]. However, in different studies, it was found that adipose tissue was more in females than in males; more than average and muscle mass was significantly higher in boys than girls $[23,24]$. Although BMI is a simple criterion used in the definition of obesity, it is not an adequate criterion [25]. 
Table 4. Change in BMI, body fat ratio and waist/hip ratio by age

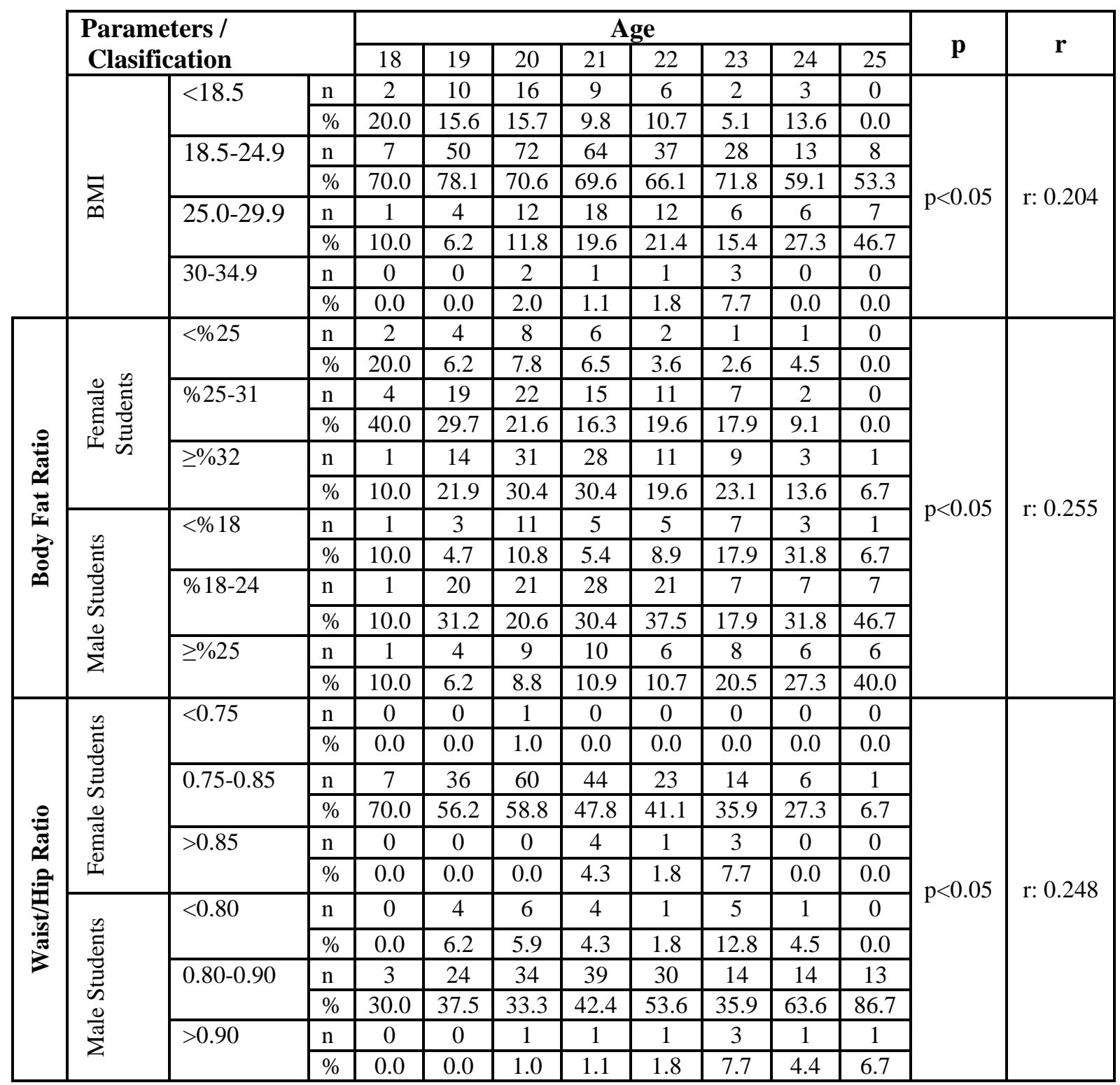

This study along with similar studies [26] shows that using only BMI in the definition of obesity will not be sufficient. It can be said that body analysis devices are also important in this context. Because, according to the body analysis of the students, it was revealed that the number of females with a higher body fat ratio than normal was higher in those of male students. It is seen that the high BMI values in male students come from muscle mass $[22,26]$.

Although there are several studies on the prevalence of obesity in Turkey, the most comprehensive studies show that levels of obesity are higher in the female population than the male population [27-31].

It should not be forgotten that obesity is a complicated health problem and body composition is affected by factors such as dietary habits, levels of physical activity and social environment. Also, it is known that the hydration status of individuals in measurements made with bioelectrical impedance analysis devices is also a factor that can affect the measurements [32, 
33]. Body analysis is an important criterion for healthy weight loss in the treatment and prevention of obesity and obesity-related diseases [34].

The fact that the students are away from the family environment during their university years results in them facing difficulties in terms of nutrition and health. Studies on university students have shown that students face significant problems when it comes to these issues. Fast food products consumed fondly by university students also cause obesity [35]. Fast-food foods are high in saturated fat and very low in fiber and nutrient content.

Besides, reasons such as irregularity in the nutrition, skipping meals or overeating at meals, consumption of junk food instead of meal, and eating disorders [36] are also among the causes of obesity of university students who stay away from the family environment.

\section{CONCLUSIONS}

In conclusion, obesity emerges as the main cause of most diseases at every stage of life, which can manifest itself since childhood. In this research, it was shown that methods other than the calculation of BMI values such as Bioelectric Impedance Body Analyzer by determining waist/hip ratio, body fat ratio, total body water, muscle weight and BMR values, obesity tendencies of university students were demonstrated more comprehensively. In chronological studies done within the university students in Turkey noted an increased prevalence of obesity and the results of our study were observed to be similar. Considering that the causes of obesity are dietary habits, levels of physical activity and social environment and genetic, it is clear that more enlightening information will be obtained with detailed studies about the nutritional status of university students and obesity status. The university students gaining the habit of sufficient and balanced nutrition and being directed to regular physical activity will be effective in reducing the prevalence of obesity among university students.

\section{Acknowledgments}

Acknowledgment (optional) of collaboration or preparation assistance may be included. Please note the source of funding for the research. The authors declare that there are no conflicts of interest. All authors approved the final version of the paper.

\section{REFERENCES}

[1] World Health Organization (WHO). (2020). https://www.who.int/health-topics/obesity\#tab=tab_1

[2] T.C. Sağlık Bakanlığı Halk Sağlığı Genel Müdürlüğü Sağlıklı Beslenme ve Hareketli Hayat Dairesi Başkanlığı. (2020). https://hsgm.saglik.gov.tr/tr/obezite/obezite-nedir.html

[3] Serter R. (2003). Obezite Atlast. Roche Yayınevi, Ankara.

[4] Vecchié, A., Dallegri, F., Carbone, F., Bonaventura, A., Liberale, L., Portincasa, P., Frühbeck, G. and Montecucco, F. (2018). Obesity phenotypes and their paradoxical association with cardiovascular diseases, European Journal of Internal Medicine, 48: 6-17.

[5] Buch, A., Carmeli, E., Boker, L.K., Marcus, Y., Shefer, G., Kis, O., Berner, Y. and Stern, N. (2016). Muscle function and fat content in relation to sarcopenia, obesity and frailty of old age-an overview, Experimental Gerontology, 76: 25-32.

[6] Kaya A. (2013). Obezite ve Hipertansiyon, Turkish Journal Endocrinology and Metabolism, 2: 13-21. 
[7] Verma, S. and Hussain, M.E. (2017). Obesity and diabetes: an update, Diabetes \& Metabolic Syndrome: Clinical Research \& Reviews, 11(1): 73-79.

[8] George, M.D. and Baker, J.F. (2016). The obesity epidemic and consequences for rheumatoid arthritis care, Current Rheumatol Reports, 18(1): 6.

[9] Güleç Öyekçin, D., Yıldız, D., Şahin, E.M. and Gür, S. (2011). Depression and anxiety in obese patients, Turk Journal of Emergency Medicine, 15: 121-124.

[10] Koçak, M. and Erem, C. (2013). Obezite ve Kanser, Türkiye Klinikleri Endokrinoloji Özel Dergisi, 6: 40-44.

[11] Aksoy, A and Selen, H. (2018). The evaluation of body composition and anthropometric measurements of males aged 18-25 years, based on the regularity of physical exercise. Progress in Nutrition, 20(3): 338-343.

[12] Booth, M.L., Hunter, C., Gore, C.J., Bauman, A. and Owen, N. (2000). The relationship between body mass index and waist circumference: implications for estimates of the population prevalence of overweight, International Journal of Obesity, 24(8): 1058-61.

[13] World Health Organization (WHO). (2020). http://www.euro.who.int/en/health-topics/diseaseprevention/nutrition/a-healthy-lifestyle/body-mass-index-bmi

[14] Türkiye Beslenme Rehberi 2015 (TÜBER). (2016). T.C. Sağlık Bakanlığı, Yayın No: 1031.

[15] T.C. Sağlık Bakanlı̆̆ı Halk Sağlığı Genel Müdürlüğü Sağlıklı Beslenme ve Hareketli Hayat Dairesi Başkanlığı (2020). https://hsgm.saglik.gov.tr/tr/obezite/obezite-nasil-saptanir.html

[16] Mahan, L.K. and Raymond, J.L. (2019). Krause, Besin ve Beslenme Bakım Süreci. 14. Baskı. Nobel Tıp Kitabevleri, Ankara.

[17] Maughan, R.J. (1995). Creatine supplementation and exercise performance, International Journal of Sport Nutrition and Exercise Metabolism, 5(2): 94-101.

[18] Can, S., Arslan, E., and Ersöz, G. (2014). Güncel bakış açısı ile fiziksel aktivite, SPORMETRE Beden Eğitimi ve Spor Bilimleri Dergisi, 12(1): 1-10.

[19] Balcığlu, İ. and Başer, S.Z. (2008). Obezitenin psikiyatrik yönü, İ.Ü. Cerrahpaşa Tıp Fakültesi Sürekli Tıp Eğitimi Etkinlikleri Sempozyum Dizisi, 62: 341-348.

[20] Karaolis-Danckert, N., Buyken, A.E., Bolzenius, K., Perim de Faria, C., Lentze, M.J. and Kroke, A. (2006). Rapid growth among term children whose birth weight was appropriate for gestational age has a longer lasting effect on body fat percentage than on body mass index, The American Journal of Clinical Nutrition, 84(6): 14491455 .

[21] McLester, C.N, Nickerson, B.S., Kliszczewicz, B.M. and McLester, J.R. (2018). Reliability and agreement of various inbody body composition analyzers as compared to dual-energy x-ray absorptiometry in healthy men and women, Journal of Clinical Densitometry: Assesment\&Management of Musculoskeletal Health, 23(3): 443450.

[22] Murathan, F. (2013). Üniversite öğrencilerinde obezite sıklı̆̆l, fiziksel aktivite düzeyi ve să̆lıkl yaşam biçimi davranışlarının incelenmesi. Doktora Tezi, T.C. Fırat Üniversitesi Sağlık Bilimleri Enstitüsü Beden Eğitimi ve Spor Anabilim Dalı, Elazı̆̆.

[23] Ramirez, E., Valencia, M.E., Bourges, H., Espinosa, T., Moya-Camarena, S.Y., Salazar, G. and AlemánMateo, H. (2012). Body composition prediction equations based on deuterium oxide dilution method in Mexican children: A national study, European Journal of Clinical Nutrition, 66(10): 1099-1103.

[24] Komiya, S., Eto, C., Otoki, K., Teramoto, K., Shimizu, F. and Shimamoto, H. (2000). Gender differences in body fat of low- and high-body-mass children: Relationship with body mass index, European Journal Applied Physiology, 82(1-2): 16-23.

[25] Eker, E. and Melih, Ş. (2004). Birinci basamakta obeziteye yaklaşım, Sürekli Tıp Eğitimi Dergisi, 11(7): 246249.

[26] Ergün, A. and Erten, S.F. (2004). Öğrencilerde vücut kitle indeksi ve bel çevresi değerlerinin incelenmesi, Ankara Üniversitesi Tıp Fakültesi Mecmuası, 57(2): 57-61.

[27] Onat, A., Can, G., Yüksel, H., Ademoğlu, E., Erginel Ünaltuna, N., Kaya, A. and Altay, S. (2017). Genetic Risk Factors for Coronary Heart Diseases and Metabolic Syndrome, In TEKHARF 2017, Leadership to the Approach of Medicine World to Chronic Diseases, İstanbul: Logos Yayınevi, pp.262-275. 
[28] Hatemi, H., Turan, N., Arık, N. and Yumuk, V. (2002). Türkiye obezite ve hipertansiyon çalışması (TOHTA), Endokrinolojide Yönelişler Dergisi, 11(1): 1-16.

[29] Bağrıaçık, N., Onat, H., İlhan, B., Tarakçı, T., Oşar, Z., Ozyazar, M., Hatemi, H.H. and Yıldız, G. (2009). Obesity profile in Turkey, International Journal of Diabetes Metabolism, 17: 5-8.

[30] Türkiye nüfus ve sağlık araştırması 2018 (2019). Hacettepe Üniversitesi Nüfus Etütleri Enstitüsü, Ankara, Yayın No: NEE-HÜ-19.01.

[31] Erel, C., Uğurlu, M., Aydınlı, F., Kesici, C., Çakır, B., Özoğlu, F. and Kaplan, Y. (2004). Sağlıklı beslenelim kalbimizi koruyalım projesi araştırma raporu 2004. T.C. Sağlık Bakanlığı Temel Sağlık Hizmetleri Genel Müdürlüğü Gıda Güvenliği Daire Başkanlığı Toplum Beslenmesi Şubesi.

[32] Gültekin, T., Dasgupta, P. and Koca, Ö.B. (2014). Segmental bioelectrical impedance analysis in children aged 7-18 years living in Ankara-Turkey: age and sex difference in the measures of adiposity, Papers on Anthropology, 23(2): 23-36.

[33] Mialich, M.S., Sicchieri, F.J.M. and Jordao Junior, A.A. (2014). Analysis of body composition: a critical review of the use of bioelectrical impedance analysis, International Journal of Clinical Nutrition, 2(1): 1-10.

[34] Çetin, İ., Muhtaroğlu, S., Yılmaz, B. and Kurtoğlu, S. (2015). Biyoelektrik impedans analiz metodu ile obez çocuklarda cinsiyete göre vücut bileşimlerinin segmental olarak değerlendirilmesi, Dicle Tip Dergisi, 42(4): 449454.

[35] Satman, İ. (2016). The Obesity Problem in Turkey, Turkiye Klinikleri Gastroenterohepatology - Special Topics, 9(2): 1-11.

[36] Oğur, S., Aksoy, A. and Selen, H. (2016). Üniversite öğrencilerinin yeme davranışı bozukluğuna yatkınlıkları: Bitlis Eren Üniversitesi örneği, BË̈ Fen Bilimleri Dergisi, 5(1): 14-26. 